\title{
The Construction of Unique Baku-Batum Pipeline in the Trans-Caucasus
}

\author{
Mir-Yusif Mir-Babayev \\ Department of Industrial Ecology and Life Safety, Azerbaijan Technical University, Baku, Azerbaijan Republic
}

Emails address:

mirbabayevmiryusif@yahoo.com,mirbm0@bp.com

\section{To cite this article:}

Mir-Yusif Mir-Babayev. The Construction of Unique Baku-Batum Pipeline in the Trans-Caucasus. Engineering and Applied Sciences. Vol. 3, No. 5, 2018, pp. 129-133. doi: 10.11648/j.eas.20180305.12

Received: October 23, 2018; Accepted: November 10, 2018; Published: December 14, 2018

\begin{abstract}
Azerbaijan, which has been linked with oil for centuries, became a famous frontrunner in the world's oil industry in the 19th century. The world's first oil in large quantities is produced in Azerbaijan (Apsheron Peninsula) and much earlier than in the Americas, Europe and Asia. The main reason was that the Baku oil lies at shallow depths and come out to the surface in the form of springs. Back in 1594, well-known master from Baku Mahammad Allahyar Nurogly built in Balakhany stage oil well deeper than $35 \mathrm{~m}$, which gave a lot of oil. Also, the Baku oilmen are the first in the transport of crude oil, kerosene and other petroleum products by tankers on the sea and by rail tank cars (in 1877-1883). The world's first kerosene line Baku- Batum with a total length of 829 miles (1 mile of equals 1,066 meters) was built to pump fuel from Baku (April 1897 - July 1907). It should be noted that the international press in 1907, printing information about the world's largest kerosene pipeline with a capacity of 60 million pounds, compared this "miracle of world" with the Eiffel Tower in France and the Trans-Siberian Railway in Russia.
\end{abstract}

Keywords: Russia (Azerbaijan), Oil Pipeline, Kerosene Pipeline, Trans-Caucasus, Baku Settlements, Baku Oilmen

\section{Introduction}

Pipeline transportation in oil industry came into existence after 1860s. Until the mid-1860s oil was transported in barrels and then in cisterns. In 1863, Dmitry Mendeleyev suggested the use of pipelines for a transportation of oil from fields to oil pipelines, and in 1877 , he put forward idea about construction of oil pipelines to long distances. The same year, he visited the USA to, as he explained "...to learn the reason of flourishing of oil business in America, find out the obstacles that delay this in our country and what needs to be to remove this delay". In his fundamental works [1, 2], which was translated, into numerous languages, Mendeleyev noted that "When oil pipeline from Baku to the Black Sea will be constructed in South Caucasus (there are many of them in America, they deliver crude oil from Pennsylvania to the cost of ocean, where oil is turned into kerosene and other products), the Baku oil will give an opportunity to produce the burning oil and they, without any doubt, will find a huge market".

The first iron oil pipeline with $5-\mathrm{cm}$ diameter and 6-km length was constructed in the USA (Pennsylvania) in 1865.
In XX century, the USA possessed 10 thousand kilometers of oil pipelines connecting the Pennsylvanian oil industries with oil plants of Philadelphia, New-York, Cleveland and other cities, as well as the country had four oil pipelines directing oil to the Atlantic harbors for exporting from country. American oil pipelines mainly located on surface, but in some areas, they were under ground. In 1914, the USA had 14 thousand km, Russia only $1278 \mathrm{~km}$ of pipelines.

\section{Main Part (Content of Article)}

The first Russian oil pipeline of 9-km length, 3-inch (7.62 $\mathrm{cm})$ diameter and 80 thousands-poods delivery capacities was built in Baku in 1878, in the fields of "Nobel brothers Co." in Balakhany (Balakhany-Black city). The pipeline was designed by the talented engineers Alexander Bari and Vladimir Shukhov. The latter put forward several principles, which are being applied in pipelining until now.

In 1879, A Bari (who opened his company "Bari, Sytenko \& Co.") and V. Shukhov received an order from the oil producer G. Lianozov to construct similar oil pipeline of 11.5-versts (old Russian measure of distance equal to 3500 
feet or $1.6 \mathrm{~km} ; 12.26 \mathrm{~km})$ : second oil pipeline BalakhanyBlack city was built in 1879 , which was better quality taking into account the experience of previous work. Following the implementation of Lianozov's pipeline, "Bari, Sytenko \& Co" also received offers from other Baku industrialists Mirzoyev, Kokorev and Benkendorf. In 1884, the Baku oilfields have five pipelines (three pipelines Balakhany-Black city, as well as Balakhany-Surakhany plant and Surakhany plant Zikh spit) with total delivery capacity of more than 200 thousand poods of oil per day.

Construction of the first pipelines in Baku was carried out with great engineering skills. Shukhov noted in 1884 that "oil pipelines constructed in 1879 are operating so far uninterruptedly and their pipes, despite heavy working pressure, do not require repair works".

Design and construction of the first pipelines in Baku was of great importance and went beyond the scope of their practical use: these projects already contained the basis of the first scientific theory of design and construction of pipelines invented by V. G. Shukhov [3].

Let's note here that Shukhov achieved two important innovations while designing oil pipelines: he developed a method for pumping of heated oil residues to reduce their viscosity, which has uniform thickness of wall that doesn't depend on diameter. For implementation of the developed method in practice, he recommended to apply "tube heaters installed on a wind bore and exhaust steam in pump passes through the pipes of heater and heats the residues approaching to the pump. Being heated accordingly, the residues enter the pump, easily pass through the clappers and pipes and the coefficient of residues friction is reducing in proportion to the increase of their heating temperature. Eventually, under the known temperature it becomes equal with the oil friction coefficient. Under a good protection of pipes, the work of residue pipe turns to be as easy as oil pumping".

Running ahead, let's note that the construction of the unique pipeline (kerosene pipeline) was interrupted by the revolution of 1905 and put into operation in July of 1907.

It is necessary to underline that the idea to build the BakuBatum pipeline emerged in 1883, right after the launch of the South Caucasus railway and establishment of a direct communication along the Caspian Sea and Volga. An American engineer Herbert Twaddle was the first who tried for real construction of the Caspian-Black Sea pipeline with the purpose of self-affirmation both in Absheron and Caucasus. In 1877-1878, he and Konstantin Bodisko, bureaucrat from the Ministry of Finance, prepared four options for unique project on establishing the partnership of the Caspian-Black Sea oil pipelines. The main goal of to be established partnership was a construction of pipelines from oilfields to the ports of the Caspian, Black and Azov seas "Figure 1".

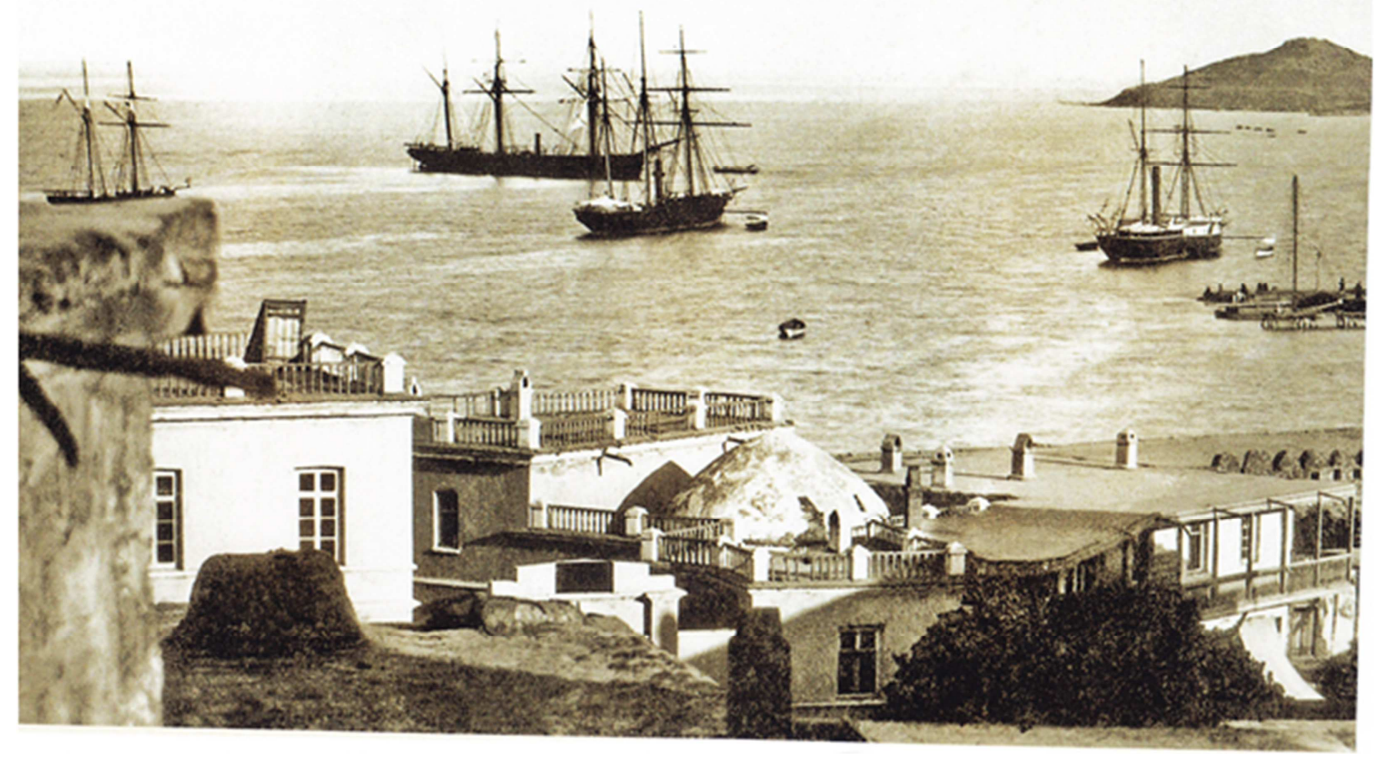

Figure 1. The harbor at Baku in 1890 (photo from Azerbaijan National Archives).

One of the experts on pipelines valid State Councilor, Director of technology I. P. Arkhipov in his report on the construction of the main pipeline noted that in this case "in Batum will set up its own "Black City" as in Baku". In his view, you can save up to 10 million rubles transferring the processing of crude oil from its production place to the place of sale. Then Ivan Arkhipov noted that "...The entire future of our exports of oil mainly depends on the reduction in price of its transport so that no decrease in price of American kerosene could not push the products of our oil from foreign markets" [4].

It would be appropriate to describe for the readers what Batum appeared to be after it became a part of the Russian Empire in August of 1878. According to the contemporary descriptions, it was a typical Turkish settlement with about 2000 population and narrow corridors instead of streets, 
where it was impossible to for carriages could hardly pass one another. However, following the development of Baku oil industry, this city started obtaining features of European city. Trade and steamship offices, as well as various foreign agencies emerged on the seafront of bay. As well-known English publicist Michael Brooks figuratively noted "Batum would have stayed a kingdom of traders if it hadn't been the Baku oil. In addition to bringing the mechanisms of industry and transportation into operation, the Baku oil was that spark, which lights many big fires". After 1936, Batum was renamed Batumi and Tiflis - Tbilisi $[5,6]$.

In November of 1886, large group of industrialists from Baku (about 50 people, including such popular persons like Haji Zeynalabdin Taghiyev, Musa Naghiyev, Emmanuel Nobel, Alexander Benkendorf, Shamsi Asadullayev and others) appealed to the Minister of State Properties requesting a prompt permission for construction of TransCaucasian pipeline. The Cabinet of Ministers adopted a decision on construction of pipeline only in 1893, but with the governmental order to involve the company of A. V. Bari. Vladimir Shukhov wrote the following about this in his notebook: "On 9 of February 1893 oil pipeline was transformed into the kerosene pipeline. On 9 of February, I and Bari visited Petersburg to negotiate this issue. The government itself is interested and therefore it will be longlasting project and high cost of the project is unlikely. Even if it happens, it is not going to be earlier than three years". These were the oracular utterances of famous engineer! Eventually it happened exactly as he had forecasted.

Dmitry Mendeleyev, seriously interested with the developing of the Baku oil business (professor several times visited Baku), did not hide his disappointment after learning about the sharp divergence of opinion among large employers in relation to the issue of construction of the Caspian-Black Sea pipeline. He wrote at that time: "If I now no longer deal with issues of Baku industry, it is mainly because of the refusal of the Baku-Batum oil pipeline, in my opinion, directed Baku oil business in undesirable for the success of Russian industry direction".

It is noteworthy that Mendeleyev, who has seriously interested in a development of the Baku oil industry (the scientist several times visited Baku), was upset when he learned about discrepancies in opinions of business leaders concerning the construction of the Caspian-Black Sea pipeline.

It is necessary to underline that the opponents of pipeline construction had, in their opinion, quite solid argumentations. For example, members of the "Baku Stock Exchange Committee" believed that the pipeline is not only not improving our chances in the struggle for foreign markets with American oil competition, but rather condemns us to fall under the blows of the Americans." And one of the most influential newspapers of St. Petersburg "New time" (Novoye Vremya) openly wrote: Do not be a terrible specter of the pipeline to which the industrialists looked upon as the coming of the Antichrist, the Caspian shipping companies could provide a bonanza for containing the capital."
They were the industrialists who zealously supported the idea of pipeline construction, including A. Rothschild, H. Z. Taghiyev, I. P. Ilimov and C. M. Baghirov. Thus, Alfonse Rothschild stood bail for this project in amount of one million rubles in four percent internal bonds to the Petersburg branch of the Lyon loan association, as well as financed the works of Shukhov on designing the project of construction $[7,8]$. He wrote to Saint-Petersburg: "I have all grounds to hope that the work we would like to realize would bring an income to the invested capital and it would promote the industrial and commercial development of the country".

One of the most famous and competent persons of his time, Haji Zeynalabdin Taghiyev delivered a speech at Baku Branch of Imperial Russian Technical Society (BB IPRTS), on 11 January of 1886. In his report on "How to come out of the oil industry crisis", Taghiyev outlined a clear organization of Baku's kerosene export through the Baku-Batum pipeline [9]. The report was topical, and it was printed and circulated among all members of BB IRTS and the local oil industrialists. Later in 1886 , as a counter to the opponents of pipeline construction, he wrote a letter to the Chief Commander of the Civilian Unit in Caucasus, A. M. Dondukov-Korsakov, about the urgent necessity to build the Caspian-Black Sea main pipeline. Upon Taghiyev's initiative, the local entrepreneurs, led by the manufacturer Aghabala Guliyev (1862-1924), set up a joint-stock company which funded the pipeline's construction.

On 23 May of 1896, the State Council of Russia adopted a decision about the construction of pipeline, which had to pass along the Trans-Caucasian railway. It instructed the engineer council of the Ministry of Communication Lines to lead the designing and construction of pipeline. Professor Schukin N. L. led the development of project. He was aware of the pipeline transportation of oil during his visit to the USA. He and engineer Vartenburg L. visited this country under the instruction of Communication Lines Minister to get an acquaintance about the construction of pipeline. Having returned to Russia, they decided to commence a construction of the kerosene pipeline from Mikhailovo to Batum (the most difficult field for delivery of railway cisterns with oil products) with delivery capacities of 980 thousand tons in 300 days of operation per year. The internal diameter of pipeline was settled considering the average density of kerosene $-820 \mathrm{~kg} / \mathrm{m}^{3}$, and recommended velocity -1.5 $\mathrm{m} / \mathrm{sec}$.

Shchukin Nikolay Leonidovich (1848-1924) - a famous scientist in the field of railway transport, the designer of locomotives. In 1873 graduated from the St. Petersburg Institute of Technology, later taught at the same institution, from 1889 he is Professor. In addition, Shchukin taught at the Military Academy of Engineering in 1883- 1907. In his project-built steam locomotive $\mathrm{H}$ series with axial and formula 1-3-0 steam locomotive with axial formula 0-4-0. He participated in the drafting of a steam locomotive SHC (in his name and was subsequently named the locomotive) and designed the carriages of Nikolaev railway and freight cars with 1,200 pounds of payload. According to the project of 
Shchukin was built the longest in the world (at that time) kerosene pipeline Baku-Batum, a length of about $900 \mathrm{~km}$. In 1910-1916 he was a deputy minister of communications, as well as chairman of the Commission of the rolling stock with the Engineering Council of the Ministry of Means Communication. He led the technical council for the construction of the locomotive's system by Y. M. Gakkel.

It must be noted that at that time the world practice didn't experience a construction of such a long kerosene pipeline along the rail way bed. Lasting transportation of kerosene, possessing large capacity for spills and evaporation, interfaced with risk, especially in neighborhood with cisterns full of oil products and passenger wagons. Taking to the account the fire risk, N. L. Schukin (he implemented the whole hydraulic estimation of pipeline) prepared the instruction, which set forth quite tough requirements to the quality of pipes and their compounds: their outside diameter could be increased just by 1.5 , internal - by $1 \%$, and ovality was accepted less than $2 \mathrm{~mm}$.

According to the government's decision, pipes were delivered from Russian plants in Mariupol, Yekaterinoslav and Sosnovitsy (station on Warsaw-Vienna railway). Length of pipe shouldn't be less than $4.6 \mathrm{~m}$ and the triangular thread must be made on their ends, implemented with inclination to the end. Such type of thread, which ensures the maximum impermeability of pipe compounds, has been adopted from the plant in Petersburg (USA).

The pipeline project was widely discussed: big engineersmechanics and hydrodynamics, as well as invited specialists (for instance, G. Merchnik, engineer of communication lines and author of the book on motion of kerosene and oil in pipes) participated at sessions. Preparatory works for construction of the Baku-Batum pipeline started in September of 1896: it was collected the layouts of road bed and bridges with indication of pipe installations, as well as the locations of boiler and pumping stations. Almost $43 \mathrm{~km}$ of pipes were installed till February of 1899; $144 \mathrm{~km}$ - till 22 of June 1899. It is noteworthy that $51 \mathrm{~km}$ of these pipelines were underground and $93 \mathrm{~km}$ - on surface.

American company "Worthington" from Brooklyn was supplying for pipeline the piston, direct acting compound pumps with steam engine; two working and one reserve pump were installed on each stage of the Mikhaylovo-Batum kerosene pipeline. To prevent kerosene leaks in case of accidents, float collars were installed on each 2-4 km of the kerosene pipeline: the automatic device was switching the pumps off when pressure in the pipeline was decreasing to $15 \%$.

Here we should note that the construction of the most complex part of the Baku-Batum (Mihaylovo-Batum), length $227.5 \mathrm{~km}$ guided by engineer L. Wartenburg and the engineer-technologist V. Nechayev, who graduated from St. Petersburg Practical Technological Institute. The construction lasted 3 years and 4 months and was completed in March 1, 1900. At the opening ceremony, held on 2 July 1900 at the station Mihaylovo, there were the Chief Commander of civil part of the Caucasus, General of Infantry G. Golitsyn, Tiflis governor Colonel I. Svechin, head of the Excise control of the Transcaucasian region L. Pershke and chief of the Transcaucasian Railway, a railway engineer E. Vedeneyev.

Following the intensified development of the Baku oil industry and great demand to kerosene abroad (thanks to Russian supplies France was covering $70 \%$ of its needs for kerosene, Egypt - 97\% and England - half of its needs) Nicolay II promulgated a decision of the Supreme Approving Board on necessity of final construction of the Baku-Batum kerosene pipeline. On 30 of December 1904 second sector of 140-km pipeline from Agh-Tala (in $21 \mathrm{~km}$ from Tiflis towards Baku) to Mikhaylovo was opened. The third and very eastern sector of the Baku (Black city) - Agh-Tala kerosene pipeline of 514-km length was opened on 1 of June 1906. Eventually, on 21 of July 1907 the unique Baku-Batum kerosene pipeline with 16 pumping stations and maximum capacity of 800 thousand tons per year, which was constructed along the Trans-Caucasian railway, was fully put into operation.

\section{Results and Discussion}

The first oil pipeline in imperial Russia $-9 \mathrm{~km}$ in length, 3 inches in diameter and with a capacity of 80000 poods - was built in Baku in 1878, from the Nobel Brothers fields in Balakhany to the black city in Baku.

An American engineer, Herbert Tweddle, was the first to try at construction of a Caspian-Black Sea pipeline (from Baku to Batum).

Industrialists (oilmen), who zealously supported the idea of pipeline construction, included Alphonse Rothschild and Haji Zeynalabdin Taghiyev.

The first main pipeline Baku-Batum, which was the longest pipeline in the world at that time, with $200-\mathrm{mm}$ diameter and more than $885-\mathrm{km}$ length, was constructed in 10 years. The official opening of pipeline took place on 24 of July 1907 in Tiflis. The government commission taking over the pipeline expressed its gratitude to all interested parties for active participation in the pipeline construction, which was compared with such achievements like the Eiffel Tower in Paris and Trans-Siberian railway in Russia [8].

Dmitry Mendeleyev greeted with fervor the launch of pipeline and noted the role of Rothschild's company, Caspian-Black Sea Society, in design and construction. He noted that: "...technological achievements in Baku became possible for heavy industrialists only... I'll al-ways support a struggle of big industrialists with small ones and join the side of lattes, as I consider them to be a real regulator of Russian industrial businesses. I know that Nobels and Rothschilds can stand up for themselves. It does not mean at all that only small enterprises should exist, and big ones must be pressed out - no, they are majors and obviously they are more necessary and important, they make the real achievement. I'll support with fervor big enterprises too if things will be overplayed". 


\section{Conclusion}

Future destiny of the Baku-Batum pipeline was as following: in 1925, the USSR's State Commission decided to re-equip the kerosene pipeline into the oil pipeline, to start oil processing in the Batum's refinery. Such a procedure of reequipment became possible, as in 1917 (from June to December), 254 thousand tons of oil was transported through this pipeline as a test; while the first party of kerosene was pumped via restored pipeline after Civil War in Russia on 22 of May 1921 [10].

Batching of gasoline and oil on pipeline began in 19301931 (on the proposal and methodology of engineer $\mathrm{V}$. Kashcheyev). Russia's first main pipeline successfully and efficiently served until 1943, when it was stopped during the German offensive in the Caucasus, disassembled and the pipes were transported to the East. Experts, who dismantled the pipeline were surprised with what skill and inconceivable margin of safety it was built. Hastily laid between the Volga and the Ural, the pipeline provides the raw material from the fields of Kuybyshev to refineries in Sverdlovsk, Nizhny Tagil, Chelyabinsk and Perm, working on the front. After the collapse of the Soviet Union it was replaced by pipeline section of the Baku-Tbilisi-Ceyhan oil pipeline and the BakuSupsa oil pipeline.

The revolution of 1917 brought about changes in the development of the Baku oil business, to the credit of the Bolsheviks should be noted that they are, despite the predictions of Western experts, not only restored the destroyed oil fields, but also made radical changes in production technology (introduction of deep well pumps and machine-rocking). Already in May 1921, the Baku-Batum pipeline begun to work, and the Baku-quality oil flowed into Europe: for the young Soviet country this oil was almost the only commodity to obtain hard currency. In 1928, the export of oil from Russia to 4 times greater than its export in 1913; and the subsequent electrification of pumping wells has led to a sharp increase in oil production - in 1941 in Baku, it was 23.5 million tons $(71.4 \%$ of the total oil production in the USSR).

The main pipelines in the USSR from 1917 to 1926 have not been built, at which time it was put into operation $600 \mathrm{~km}$ of pipelines technological infield destination. However, from 1926 until the beginning of World War II, it was built several oil pipelines: Grozny-Tuapse, Makhachkala-Grozny, etc. During the World War II and after 1945, it was a new oil history, full of remarkable feats of the Baku oil workers and scientists.

This is a short history of the construction of the first in the world Baku-Batum pipeline.

\section{Acknowledgements}

I express my gratitude to the collaborators of the Azerbaijan National Archives and the Azerbaijan State Library named after Mirza Fatali Akhundov for assistance in the work on the article.

\section{References}

[1] Mendeleyev D.I. "Foundations of Chemistry" - SaintPetersburg, $1895,6^{\text {th }}$ edition.

[2] Mendeleyev D.I. Oil industry in the Pennsylvania and Caucasus. Proceedings, v.10 - Moscow, Publishing House of USSR Academy of Sciences, 1949.

[3] Mir-Babayev M.F. Vladimir Shukhov and Russian oil industry. - "Territory of the Neftegas", Moscow, 2004, \#10, pp. 60-63.

[4] "Baku news" (Bakinskie novosti) newspaper, 1894, № 57-59.

[5] Mir-Babayev M.F. The Rothschild brother's contribution to Baku's oil industry - "Oil-Industry History" (USA), 2012, v. 13, no. 1, pp. 225-236.

[6] Mir-Babayev M.F. Russian Oil Business and the Rothschilds"Oil Gas Chemistry”, M., 2002, № 4, pp. 44-47.

[7] “Kaspy” (Caspian) newspaper, 1888, \# 155.

[8] Polonsky L.A. Bank's house of Rothschild brothers in Baku. Baku, Publishing house Azerneshr, 1998.

[9] "Mining Magazine" (Gorny Journal) newspaper, 1887, v. 1, p.18.

[10] Mir-Babayev M.F. Concise history of Azerbaijani oil. The second book - Baku, Publishing house SOCAR, 2013. 